\title{
Erratum to: Lost in travel or a different conception? (Mis-)appropriation of transformative learning theory in the Republic of Korea
}

Dae Joong Kang ${ }^{1} \cdot$ Sungmin $\mathrm{Cho}^{2}$

Published online: 24 June 2017

(c) Education Research Institute, Seoul National University, Seoul, Korea 2017

\section{Erratum to: Asia Pacific Educ. Rev.}

\section{DOI 10.1007/s12564-017-9481-x}

Unfortunately Table 1 and Table 2 have been interchanged in the original publication of this article. The corrected tables are given in this erratum.

The online version of the original article can be found under doi:10.1007/s12564-017-9481-x.

Dae Joong Kang

kdj@snu.ac.kr

1 Department of Education, Seoul National University, 1 Gwanak-ro, Gwanak-gu, Seoul 08826, Republic of Korea

2 Seoul National University, Seoul, Republic of Korea 
Table 1 A summary of the empirical studies

\begin{tabular}{|c|c|c|c|}
\hline Nos. & $\begin{array}{l}\text { Empirical } \\
\text { studies }\end{array}$ & Purpose & Methods \\
\hline 1 & Lee (1999) & $\begin{array}{l}\text { Tried to find out the meaning and possibility of transformative learning with } 20 \text { elders } \\
\text { participating in elder's learning center }\end{array}$ & Participant observation, interview \\
\hline 2 & Park (2003) & $\begin{array}{l}\text { Examined the nature of changes in meaning structures among } 25 \text { international } \\
\text { graduate students from East Asia attending at Christian higher learning institutions in } \\
\text { the US }\end{array}$ & $\begin{array}{l}\text { Interview (once for each for } \\
50-90 \mathrm{~min} \text { ) }\end{array}$ \\
\hline 3 & Lee (2007) & $\begin{array}{l}\text { Explored triggers for the cross-cultural adaptation and transformative learning of two } \\
\text { Korean-American immigrant families }\end{array}$ & $\begin{array}{l}\text { Interview (once for each for } \\
60-120 \mathrm{~min} \text { ) }\end{array}$ \\
\hline 4 & $\begin{array}{l}\text { Lee and } \mathrm{Na} \\
(2009)\end{array}$ & $\begin{array}{l}\text { Explored the meaning of newly formed viewpoints of six married female immigrants } \\
\text { who successfully settled down in Korea }\end{array}$ & $\begin{array}{l}\text { Participant observation, interview } \\
\text { (twice for each) }\end{array}$ \\
\hline 5 & Jung (2009) & $\begin{array}{l}\text { Attempted to analyze frame of reference of four early childhood teachers who } \\
\text { participated in a multicultural teacher training program }\end{array}$ & $\begin{array}{l}\text { Non-participant observation, } \\
\text { interview, document analysis }\end{array}$ \\
\hline 6 & $\begin{array}{l}\text { Park and Jo } \\
\text { (2009) }\end{array}$ & $\begin{array}{l}\text { Explored the meaning and possibility of transformative learning with } 42 \text { pre-service } \\
\text { early childhood teachers who had been engaged in vegetable gardening }\end{array}$ & $\begin{array}{l}\text { Group interview (once for each } \\
\text { for } 40-60 \mathrm{~min} \text { ), document } \\
\text { analysis }\end{array}$ \\
\hline 7 & Park (2009) & $\begin{array}{l}\text { Examined how the culture of higher education shaped the meaning-making process } \\
\text { with } 30 \text { middle-aged women in a higher education }\end{array}$ & $\begin{array}{l}\text { Interview (once for each for } \\
60-90 \mathrm{~min} \text { ) }\end{array}$ \\
\hline 8 & $\begin{array}{l}\text { Park and Jo } \\
\text { (2010) }\end{array}$ & $\begin{array}{l}\text { Explored how five early childhood teachers understood learning experience and made } \\
\text { up their own meanings with transformative learning theory }\end{array}$ & $\begin{array}{l}\text { Non-participant observation, } \\
\text { interview (five or six times for } \\
\text { each), text analysis }\end{array}$ \\
\hline 9 & Cho (2010) & $\begin{array}{l}\text { Examined the (re)construction of learning experience and identity of } 11 \text { North Korean } \\
\text { immigrants in the process of adaptation to the Republic of Korea }\end{array}$ & $\begin{array}{l}\text { Interview (once for each for } \\
120-180 \mathrm{~min} \text { ) }\end{array}$ \\
\hline 10 & $\begin{array}{l}\text { Kim et al. } \\
\quad(2013)\end{array}$ & $\begin{array}{l}\text { Investigated adult learners' learning experiences in classrooms that were designed to } \\
\text { facilitate transformative learning with four international doctoral students }\end{array}$ & $\begin{array}{l}\text { Interview (twice for each), } \\
\text { document analysis }\end{array}$ \\
\hline 11 & Kim (2013) & $\begin{array}{l}\text { Examined relation of transformative learning and moral development with eight } \\
\text { current or former female politicians who experienced social activities }\end{array}$ & $\begin{array}{l}\text { Interview (once for each for } \\
120 \mathrm{~min} \text { ), document analysis }\end{array}$ \\
\hline 12 & Park (2013) & $\begin{array}{l}\text { Explored the possibility of transformative learning with } 22 \text { pre-service early childhood } \\
\text { teachers taking a course in the university }\end{array}$ & $\begin{array}{l}\text { Group discussion, document } \\
\text { analysis }\end{array}$ \\
\hline 13 & $\begin{array}{l}\text { Kim and } \\
\mathrm{Na}(2013)\end{array}$ & $\begin{array}{l}\text { Describe the turnover experience of eight executive secretaries and their } \\
\text { transformative learning process }\end{array}$ & $\begin{array}{l}\text { Interview (two or three times for } \\
\text { each) }\end{array}$ \\
\hline 14 & Jun (2014) & $\begin{array}{l}\text { Explored the sociocultural transformative learning experience of } 10 \text { Social Network } \\
\text { Service Users }\end{array}$ & $\begin{array}{l}\text { Interview (once for each for } \\
60-120 \text { min), document } \\
\text { analysis }\end{array}$ \\
\hline 15 & Kim (2014) & $\begin{array}{l}\text { Examined the process of cognitive transformation in the life of three feminist women } \\
\text { who majored in women's studies by looking at critical life events }\end{array}$ & $\begin{array}{l}\text { Interview (five times for each for } \\
180-240 \mathrm{~min} \text { ) }\end{array}$ \\
\hline
\end{tabular}

Table 2 Tri-level category of four core concepts

\begin{tabular}{|c|c|c|c|c|}
\hline Symbols & Disorienting dilemmas & Critical reflection & Seeking agreement & Taking action \\
\hline $\mathrm{O}$ & $\begin{array}{l}\text { Involving problem- } \\
\text { posing }\end{array}$ & $\begin{array}{l}\text { Involving premise } \\
\text { reflection }\end{array}$ & $\begin{array}{l}\text { Involving rational discourse and } \\
\text { consensus building }\end{array}$ & $\begin{array}{l}\text { Involving changed actions integrated } \\
\text { with new perspective }\end{array}$ \\
\hline$\Delta$ & $\begin{array}{l}\text { Identifying with a } \\
\text { (negative) event }\end{array}$ & $\begin{array}{l}\text { Involving content or } \\
\text { process reflection }\end{array}$ & $\begin{array}{l}\text { Involving only received agreement } \\
\text { or communication }\end{array}$ & $\begin{array}{l}\text { Involving a changed action in a specific } \\
\text { context }\end{array}$ \\
\hline $\mathrm{X}$ & $\begin{array}{l}\text { No convincing } \\
\text { evidences }\end{array}$ & No convincing evidences & No convincing evidences & No convincing evidences \\
\hline
\end{tabular}

